Revista lus et Praxis, Año 19, № 2, 2013, pp. 179 - 206

ISSN 0717 - 2877

Universidad de Talca - Facultad de Ciencias Jurídicas y Sociales

"La configuración jurídica de las vías de

hecho como causa del despido disciplinario"

Pedro Irureta Uriarte

\title{
LA CONFIGURACIÓN JURÍDICA DE LAS VÍAS DE HECHO COMO CAUSA DEL DESPIDO DISCIPLINARIO*
}

\author{
THE LEGAL CONFIGURATION OF THE \\ PHYSICAL AS A CAUSE FOR THE DISCIPLINARY DISMISSAL
}

Pedro Irureta Uriarte ${ }^{* *}$

\begin{abstract}
Resumen
Las vías de hecho han sido incorporadas en el Código del Trabajo como una especial causa de despido disciplinario. A pesar de la relevancia que esta figura tiene en el sistema extintivo del contrato de trabajo, lo cierto es que no ha existido un especial debate doctrinario sobre la misma y la magnitud de casos jurisprudenciales que se hacen cargo del núcleo definitorio de la causal es bastante acotada. Desde esta perspectiva, las vías de hecho han sobrevivido en la evolución del Derecho del

Trabajo chileno como una figura singular, cuya consagración se asocia más a razones históricas que a criterios sistemáticos de regulación del despido disciplinario. Con todo, la causal ha sido configurada por la doctrina y la jurisprudencia de acuerdo a parámetros amplios que intentan separarse de la regulación penal de las lesiones y maltratos de obra. Dicha configuración estructura la causal como una infracción de mera actividad, dentro de la cual caben todo tipo de agresiones físicas, riñas, peleas o pendencias. Asimismo, la calificación de la causal ha estado rodeada de circunstancias agravantes, atenuantes o eximentes que la jurisprudencia utiliza para determinar el nivel de gravedad de la conducta.
\end{abstract}

ABSTRACT

The physical acts have been incorporated into the Labour Code as a special cause for disciplinary dismissal. Despite the relevance that this figure has in the discontinuance of employment contract system, the fact is that there has been no special doctrinal debate about it, and the magnitude of the jurisprudential cases which take charge of defining the causal core is quite limited. From this perspective, the physical acts have actually survived in the history of Chilean labor law as a singular figure, whose consecration is more associated with historical reasons than to systematic criteria of disciplinary dismissal regulation. Nevertheless, the cause has been shaped by the

\footnotetext{
* Trabajo recibido el 14 de noviembre de 2012 y aprobado el 10 de abril de 2013.

Abreviaturas: AL (Actualidad Laboral); CCOM (Código de Comercio); CPR (Constitución Política de la República); CT (Código del Trabajo); GJ (Gaceta Jurídica); RDJ (Revista de Derecho y Jurisprudencia y Gaceta de los Tribunales); RFM (Revista Fallos del Mes); RPS (Revista de Política Social); RTSS (Revista de Trabajo y Seguridad Social).

${ }^{*}$ Licenciado en Derecho por la Pontificia Universidad Católica de Chile, Doctor en Derecho por la Universidad Complutense de Madrid, Profesor Titular de Derecho del Trabajo de la Universidad Alberto Hurtado. Correo electrónico: piruret@uahurtado.cl.
} 
doctrine and jurisprudence according to broad parameters that attempt to separate from the criminal regulation of injuries and force abuse. This configuration structures the cause as an infraction of mere activity, where any type of physical aggression, quarrel or fight can be included. Additionally, the qualification of this cause has been surrounded of aggravating, extenuating or liability exemption circumstances that the case-law uses for determining the level of seriousness of the behaviour.

\author{
Palabras Clave \\ Despido, Vías de hecho, Maltrato \\ KEYWORDS \\ Dismissal, Physical acts, Maltreatment
}

\title{
I. INTRODUCCIÓN
}

A diferencia de otros ordenamientos, el Código del Trabajo chileno establece una serie de causas disciplinarias de despido, de distinta naturaleza, y que en muchos casos su fundamentación se encuentra más vinculada a cuestiones históricas que a razones de orden meramente jurídico. De esta forma, se ha optado por un catálogo más o menos casuístico, que otorgue mayor seguridad en su aplicación y que contemple cláusulas de cierre relativamente flexibles dentro de las cuales es posible encuadrar los incumplimientos contractuales de cierta gravedad. Esta práctica es coincidente con algunos sistemas laborales hispanoamericanos, aun cuando habrá que reconocer que el detalle de las causas varía de acuerdo a la realidad de cada uno de ellos.

Dentro del catálogo de causas, existen algunas muy particulares. Así ocurre, por ejemplo, con los maltratos u ofensas físicas que ejecute el trabajador en contra del empleador (u otros compañeros de labores) y que genéricamente el Código las denomina vías de hecho. En efecto, el artículo 160 № 1, letra c) CT, indica que el contrato de trabajo termina sin derecho a indemnización alguna cuando el empleador le ponga término invocando una o más de las siguientes causales: "1. Alguna de las conductas indebidas de carácter grave, debidamente comprobadas, que a continuación se señalan: (...) c) Vías de hecho ejercidas por el trabajador en contra del empleador o de cualquier trabajador que se desempeñe en la misma empresa".

Las vías de hecho, junto a otras hipótesis extintivas, fueron incorporadas con diversa redacción en las primeras leyes sociales tanto para el caso del despido de los obreros como de los empleados. En el caso de los obreros, el artículo $5^{\circ} \mathrm{N}^{\circ} 6$ de la Ley $\mathrm{N}^{\circ} 4.053$ (de 1924) facultó el término inmediato del contrato cuando el trabajador incurría en conductas propias de "falta de probidad, vías de hecho, injurias y conducta inmoral". En el supuesto de los empleados, la Ley № 4.059 (de 1924) procedió de forma distinta, siguiendo de cerca la regulación que sobre esta temática establecía el Código de Comercio. De esta manera, 
para los empleados las primeras regulaciones utilizaron una redacción que aún permanece en el texto mercantil" , y que básicamente sancionaba las "injurias o actos que, a juicio del Juzgado de Comercio, comprometan la seguridad personal, el honor o los intereses del comitente". La referencia a los actos que comprometieran "la seguridad personal" fue aceptada como una redacción suficientemente apta para reprochar conductas tales como las riñas, las amenazas o lisa y llanamente la violencia en el actuar dentro de la empresa.

A partir de la reforma de la Ley $N^{\circ} 16.455$, de 1966, y habiéndose ampliado el concepto de trabajador tanto para obreros como empleados, el régimen laboral chileno mantuvo la expresión "vías de hecho" como una figura extintiva unitaria que permitía describir los actos de agresión física, las riñas o las pendencias, ya fuese en contra del empleador o bien entre compañeros de labores. Y lo cierto es que, hasta el día de hoy, las diferentes reformas al sistema de despido en Chile han mantenido este vocablo de forma inalterada convirtiendo a las vías de hecho en la fórmula laboral que permite sancionar los malos tratos de obra o las ofensas físicas que se produzcan al interior de la empresa. Desde esta perspectiva, la única modificación sustantiva que experimentó esta causal (dejando de lado los cambios incorporados por la Ley $\mathrm{N}^{\circ}$ 16.455) se produjo con la reforma introducida por la Ley № 19.759, de 2001, la cual centró el ilícito en actos exclusivamente ejecutados por el trabajador en contra del empleador o de cualquier trabajador que se desempeñe en la misma empresa.

En este orden de ideas, la expresión vías de hecho constituye una referencia genérica y omnicomprensiva de cualquier maltrato de obra o agresión física provocada por el trabajador. Dentro de ellas caben, desde luego, las riñas, golpes, peleas, enfrentamientos y reacciones desproporcionadas que, en definitiva, menoscaban la dignidad de la víctima y la disciplina interna de la empresa. De cierta manera, el Código parte de la base que la sola ocurrencia de este tipo de conductas, sin justificación ni provocación previa, es lo suficientemente grave para extinguir el vínculo contractual, ya que un comportamiento de esta naturaleza implica un serio atentado tanto para "la disciplina de la faena, como para la propia seguridad de las personas y vidas que se encuentran en peligro" ${ }^{2}$. Por tanto, y a diferencia de lo que ocurre en materia penal ${ }^{3}$, el bien jurídico protegido no es tanto la integridad corporal del empleador o del compañero de

\footnotetext{
${ }^{1}$ Véase artículo 333 del CCOM.

2 Véase en esta línea la fundamentación otorgada por la jurisprudencia bajo la vigencia del Código del Trabajo de 1931: Sentencia de la Excma. Corte Suprema de 24 de junio de 1946, RDJ T. XLV, sección tercera, 1948, p. 23; y sentencia de la Excma. Corte Suprema de 14 de noviembre de 1944, RDJ T. XLII, sección primera 1945, p. 403.

${ }^{3}$ Véase Garrido Montt, Mario, Derecho Penal, T. III, Editorial Jurídica de Chile, cuarta edición, Santiago, 2010, p. 148.
} 
labores (que en parte, también, se encuentra presente), sino que la disciplina básica que debe existir en la actividad laboral.

Curiosamente, y a pesar de la relevancia que esta temática adquiere en el sistema de relaciones laborales, este tipo de causas de despido disciplinario ha sido asumido por el ordenamiento legal sin mayor análisis doctrinario. Más allá del desarrollo jurisprudencial, en nuestro país no existen estudios monográficos sobre las causas de despido disciplinario y ni siquiera las obras generales se han adentrado en resolver la totalidad de las implicancias jurídicas de cada una de las hipótesis extintivas.

Consecuente con lo anterior, desde la época inicial del Derecho del Trabajo chileno, la configuración de las vías de hecho ha sido resorte casi exclusivo de la valoración jurisprudencial. El problema, no obstante, es que este desarrollo jurisprudencial ha estado más centrado en causas genéricas al estilo de la falta de probidad o el incumplimiento grave de las obligaciones, relegando a un segundo plano otro tipo de causales. En rigor, no existe un número significativo de sentencias que permitan estructurar una configuración acabada de otras causas disciplinarias; cuestión que resulta especialmente predicable de las vías de hecho.

En el presente artículo se busca identificar esta precisa causa de despido, establecer su configuración legal y jurisprudencial, delimitar sus contornos y resolver las dificultades prácticas que surgen de la aplicación de un término genérico que no ha tenido mayor análisis en la dogmática. A partir de situaciones casuísticas, se busca extraer conclusiones generales para esta específica causa de despido disciplinario. Para estos efectos, y ante la referida escasez de estudios de la causal por parte de la dogmática nacional, se ha recurrido en distintos pasajes al comentario de la doctrina comparada, lo cual ha permitido ilustrar y enriquecer las nociones sobre la exacta configuración jurídica de esta figura. Esa misma doctrina comparada entrega en muchos casos elementos que ayudan a obtener conclusiones plenamente aplicables al derecho chileno. En lo que respecta a la jurisprudencia vinculada a las vías de hecho, en la preparación de este artículo se ha efectuado una revisión general de los fallos dictados por los tribunales superiores de justicia. Así, por ejemplo, se revisaron fuentes de conocimientos tales como RDJ, GJ, RFM, desde sus inicios hasta la fecha. Adicionalmente, se consultaron bases electrónicas de acceso público.

\section{LA CONFIGURACIÓN DE LAS VÍAS DE HECHO}

\section{Una conducta indebida, grave y debidamente comprobada}

Como es ampliamente sabido, la configuración de las causas disciplinarias establecidas en el art. $160 \mathrm{~N}^{\circ} 1 \mathrm{CT}$ exige la concurrencia de una trilogía de requisitos: la conducta debe ser indebida, grave y comprobada. La falta de jus- 
tificación de la conducta deja en evidencia su carácter indebido; es decir, para que el acto cuestionado cumpla con el estándar exigido resulta imprescindible que se trate una conducta no amparada por el iter legal y contractual, y que desde luego no tenga eximentes. Desde la perspectiva laboral, la conducta indebida está constituida por la realización de actos que carecen de justificación contractual y normativa. La ilicitud, por lo tanto, surge de un desborde del contenido obligacional cuyo núcleo definitorio está conformado por el programa contractual y por el marco normativo. De esta forma, la ejecución de una conducta indebida refleja la vulneración de un deber legal o contractual, sin que exista justificación en algún derecho o sin que se presente una causa que elimine la reprochabilidad a su autor.

La comprobación, por su parte, deja al descubierto un estándar mínimo que asegure la acreditación de los hechos fundantes de la causal. Dicha acreditación logra constatar objetivamente los presupuestos materiales de la infracción (más allá de los elementos subjetivos que deben concurrir en cada caso en particular), permitiendo que el juez laboral declare la procedencia del despido ${ }^{4}$. Por cierto, las vías de hecho no pueden fundarse en la mera sospecha o en la simple posibilidad: debe existir una fundamentación acabada en la realidad ${ }^{5}$. Y es esa fundamentación la que permite comprobar que el trabajador ha realizado actos reñidos con la disciplina interna y que el acto cuestionado no constituye una mera imprudencia sin connotación jurídica ${ }^{6}$. Si estas exigencias de comprobación no concurren, entonces resulta imposible aplicar la causal?

La gravedad de la conducta, por último, exige que el acto cuestionado sea de "mucha entidad e importancia" (cuestión que necesariamente tendrá que evaluarse en sede judicial) ${ }^{8}$, ya que por muy reprochable que sea una conducta no necesariamente tendrá que constituir una causal justificada de terminación pues los actos reprochados no reúnen la exigencia de gravedad a que se refiere

\footnotetext{
${ }^{4}$ Véase, en el plano de la doctrina comparada, pero plenamente aplicable al caso chileno, Montora Melgar, Alfredo, Derecho del Trabajo, Tecnos, vigésimo novena edición, Madrid, 2008, p. 476.

${ }^{5}$ Véase, por ejemplo, sentencia de la Excma. Corte Suprema de 15 de abril de 1993, RFM № 412, 1993, p. 60; y sentencia de la Excma. Corte Suprema de 04 de marzo de 1992, GJ No 141, 1992, p. 79.

${ }^{6}$ Véase, por todas, sentencia de la Iltma. Corte de Apelaciones de Santiago de 28 de junio de 1999, G) № 228, 1999, p. 165.

${ }^{7}$ Véase sentencia de la Excma. Corte Suprema de 30 de octubre de 2003 (Causa Ingreso Corte № 7882003): "Corresponde declarar injustificado el despido de un trabajador por la causal del artículo 160 № 1 letra c) del Código del Trabajo, esto es, por vías de hecho en contra de otro trabajador, si no se acredita en juicio que haya sido efectivamente el despedido quien dio inició o agredió de alguna forma violenta al otro trabajador, el cual le propino un corte con cuchillo, pues no consta ni testimonio ni otra prueba que acredite la agresión por parte del despedido".
}

${ }^{8}$ Véase por todas sentencias de la lltma. Corte de Apelaciones de Santiago de 27 de abril de 1998, GJ № 216, 1998, p. 189. 
el Código ${ }^{9}$. Para que un hecho sea grave, resulta preciso que su relevancia y magnitud sean manifiestas, cuestión que permite desechar las simples infracciones aisladas, las imprudencias realizadas con justa causa de error, o las faltas mínimas, ya que ellas no están rodeadas de la gravedad suficiente para poder extinguir el contrato de trabajo ${ }^{10}$. Sin perjuicio de ello, la gravedad puede emanar de un sólo hecho o bien de la reiteración de una serie de actos de menor entidad pero que, en su conjunto, revelan la gravedad exigida.

En el caso de las vías de hecho, tradicionalmente la jurisprudencia ha tendido a ser menos tolerante con este tipo de conductas que con otras causas disciplinarias de similar connotación (v. gr., las injurias). Y esa menor tolerancia tiene implícita la tesis de que los maltratos de obra, las riñas, las actuaciones violentas, son siempre graves. Es decir, la relevancia de la conducta infraccional es evidente en las vías de hecho pues en definitiva la conducta presenta menores márgenes de interpretación. Habrá que reconocer, con todo, que este criterio jurisprudencial ha sido objeto de matizaciones motivadas fundamentalmente por el gradualismo en la valoración de la sanción. En el fondo, se reconoce que la evaluación de la gravedad exige un examen casuístico, pormenorizado, que permite distinguir las circunstancias subjetivas que determinaron el comportamiento del trabajador, cuestión que, en definitiva, puede llevar a suponer otro tipo de reacciones punitivas ${ }^{11}$.

\footnotetext{
${ }^{9}$ Véase por todas sentencias de la Iltma. Corte de Apelaciones de Valparaíso de 20 de octubre de 1983, G) $N^{\circ} 40,1983$, p. 113, y sentencia de la Iltma. Corte de Apelaciones de Santiago de 30 de julio de 2004, GJ No 289, 2004, p. 308. Véase, además sentencia de la Iltma. Corte de Apelaciones de Santiago de 11 de julio de 1997, GJ № 205, 1997, p. 165, la cual le resta gravedad a la circunstancia de "lanzarle un objeto pesado a un compañero producto de una discusión (...)". Con todo, hay jurisprudencia que ha medido la gravedad en base a la reiteración: "Quedan comprendida en la causal de vías de hecho, las actitudes agresivas y todas las actuaciones violentas contra sus semejantes; (...) actuaciones que dan origen a un despido cuando revisten el carácter de graves y reiteradas" (sentencia de la Excma. Corte Suprema de 30 de octubre de 2003. Causa Ingreso Corte № 788-2003).
}

${ }^{10}$ Véase sentencia de la Excma. Corte Suprema de 23 de abril de 1998, RDJ, T. XCV, sección tercera, 1998, p. 45: “(...) es lógico concluir que no basta para constituir la causal de que se trata el que determinada conducta sea digna de reproche. Por el contrario, es menester -además- que ella esté revestida de una entidad tal que pueda ser capaz de provocar efectos o consecuencias tan radicales como los apuntados. En ese orden ideas, si bien pudiera aceptarse que el comportamiento establecido, en la especie respecto del trabajador, pueda ser merecedor de reprobación (...) no lo es menos que, de suyo, no configuran la causal de que se trata". Véase en la misma línea sentencia de la lltma. Corte de Apelaciones de Valparaíso de 20 de octubre de 1983, GJ № 40, 1983, p. 113.

${ }^{11}$ Véase, a este respecto, la posición sostenida por la doctrina comparada, y que adquiere relevancia para el caso nacional, en BAylos Grau, Antonio, "La valoración del comportamiento habitual del trabajador en el despido por malos tratos y faltas graves de respeto", RPS № 119, 1978, p. 245. Véase también AgUILERA IzQUieRdo, Raquel, Las causas del despido disciplinario y su valoración por la jurisprudencia, Aranzadi, Pamplona, 1997, p. 211, y Fernández López, María Fernanda, El poder disciplinario en la empresa, Civitas, primera edición, Madrid, 1991, pp. 244 y ss. En el plano jurisprudencial, véase sentencia de la Iltma. Corte de Apelaciones de Valdivia de 09 de agosto de 2005 (Causa Ingreso Corte 
Además que no resulta relevante el horario en que este episodio se verificó, desde que claramente se trató de un momento en que los involucrados estaban presentes en el lugar de trabajo, por y con ocasión del mismo.

\section{El núcleo de la conducta prohibida}

El artículo 160 № 1 CT incorpora a las vías de hecho dentro de un catálogo mayor de causales, indisimulablemente vinculadas por la infracción a la buena fe contractual ${ }^{12}$. Dentro de ese catálogo se encuentran, por cierto, la falta de probidad, la conducta inmoral, el acoso sexual o laboral, y las injurias, como si el conjunto de ellas formaran un todo compacto que requieren de un estudio unitario. Dentro de ese entramado se encuentran las vías de hecho.

Al consagrarla de manera directa, el legislador asume la gravedad de este tipo de faltas y muestra al mismo tiempo la intolerancia normativa frente a conductas de esta naturaleza. Y lo hace así, ya que el legislador implícitamente asume que las vías de hecho afectan de manera directa la convivencia pacífica y la disciplina en el seno de la empresa, así como la dignidad de la persona ofendida.

Como se ha dicho, las vías de hecho se relacionan, en principio, con las agresiones $u$ ofensas físicas que atentan contra la integridad corporal del empleador o de un compañero de labores ${ }^{13}$. A diferencia de otras causas disciplinarias, aquí se trata de actos de violencia y fuerza física, perceptible

No 85-2005): "Primero: Que si bien es efectivo que la riña o pelea en la que resultó lesionado un trabajador de la demandada se encuentra acreditada con la fotocopia de la sentencia pronunciada por el señor Juez del Segundo Juzgado de Policía Local de Osorno, (...) por tratarse de un hecho aislado que ocurrió en un horario coincidente con la salida del trabajo, no permite a estos sentenciadores arribar a la conclusión que nos encontremos frente a una grave infracción laboral, en los términos expuestos por la demandada, que le permitan poner término a la relación laboral (...)".

${ }^{12}$ Véase por todas sentencia de la Excma. Corte Suprema de 26 de enero de 2006 (Causa Ingreso Corte No 5058-04).

${ }^{13}$ En el plano jurisprudencial, véase sentencia de la Iltma. Corte de Apelaciones de Talca de 24 de mayo de 2011 (Causa Ingreso Corte № 67-2011): "Tercero: (...). Al respecto la sentencia en el considerando quinto entra derechamente al análisis de esta causal de despido, luego de revisar la prueba rendida en la audiencia por las partes. En primer término hace un estudio de lo que debe considerarse como vías de hecho, concluyendo que la principal característica es la agresión del físico de una persona y agresión, según el Diccionario de la Real Academia Española de la Lengua en su primera acepción es 'acto de acometer a alguien para matarlo, herirlo o hacerle daño' el cual debe ir dirigido a lo exterior de una persona, lo que forma su constitución y naturaleza. Descrito lo anterior, la sentenciadora concluye que de la prueba rendida, no emerge ningún hecho concreto alusivo a una conducta por la cual la demandante haya ejercido violencia física en contra de un compañero de trabajo. De tal modo no se observa la infracción manifiesta de las normas sobre apreciación de las pruebas conforme a las reglas de la sana crítica". Una posición similar se ha mantenido en el Derecho comparado, para el caso particular del sistema español, en GarCia Ninet, José Ignacio, "Ofensas verbales o físicas al empresario o a otras personas del entorno empresarial", Estudios sobre el despido disciplinario, Acarl, Madrid, 1992, p. 178. 
por los sentidos, y cuya tipología es variada aun cuando por regla general engloba dentro sí diversas actitudes agresivas o violentas de orden corporal ${ }^{14}$. En esta perspectiva, habrá que incluir dentro de la conducta prohibida a las "confrontaciones entre trabajadores", los "arrebatos o conductas psíquicas incontrolables"15, el "apuntar a un trabajador con un arma"16, "las clásicas bofetadas y puñetazos", "las agresiones con objetos punzantes y cortantes", las "reacciones violentas y groseras"17, las riñas o desórdenes, las contestaciones en forma violenta, así como los "empujones, patadas, lanzamiento de objetos, zarandeo de coches, peleas multitudinarias", o la retención forzosa o encierro del empleador, sus representantes o algún compañero de labores, entre otras muchas alternativas ${ }^{18}$.

Para que concurra un supuesto propio de vías de hecho no resulta estrictamente necesaria la producción de lesiones específicas. Más aún, se acepta en doctrina que la causal se configure con la simple tentativa o con la realización de actos preparatorios ${ }^{19}$. De igual forma, la frustración del acto reprochado también pone en movimiento la figura extintiva, pues se parte de la base que todas las fases del iter causal se encuentran englobadas en la hipótesis infractora. De allí que se haya concluido que el mero hecho de que dos trabajadores se desafíen a pelear es suficiente fundamento para la aplicación de la causa ${ }^{20}$. Dicho de otra manera, no resulta estrictamente indispensable para la configuración del

\footnotetext{
${ }^{14}$ Véase, entre otras, sentencia de la Excma. Corte Suprema de 08 de julio de 2010 (Causa Ingreso Corte № 2601-2010): "Séptimo: Que para configurar la causal en estudio, necesariamente se requiere la existencia de una agresión física, riñas o peleas (...)"; sentencia de la Excma. Corte Suprema de 30 de octubre de 2003 (Causa Ingreso Corte № 788-2003): "Quedan comprendida en la causal de vías de hecho, las actitudes agresivas y todas las actuaciones violentas contra sus semejantes; en general, dice relación con confrontaciones entre trabajadores, arrebatos o conductas psíquicas incontrolables; los autores constituyen una seria amenaza para sus compañeros de labor y los jefes; actuaciones que dan origen a un despido cuando revisten el carácter de graves y reiteradas, sanción que debe recaer exclusivamente en quien da origen a ellas", y sentencia de la lltma. Corte de Apelaciones de Concepción de 30 de noviembre de 2007 (Causa Ingreso Corte № 514-2007): "Las vías de hecho dicen relación con toda acción de fuerza o violencia que una persona ejecuta o realiza en contra de otra sin estar amparada por alguna norma jurídica que la justifique o la legitime".

${ }^{15}$ Véase sentencia de la Iltma. Corte de Apelaciones de Santiago de 10 de enero de 2003 (Causa Ingreso Corte No 350-2002), y sentencia de la Excma. Corte Suprema de 30 de octubre de 2003 (Causa Ingreso Corte $\mathrm{N}^{\circ}$ 788-2003).

${ }^{16}$ Véase Aguilera, Las causas, cit. nota n. 10, p. 212.

${ }^{17}$ Véase sentencia de la Iltma. Corte de Apelaciones de Concepción de 30 de noviembre de 2007 (Causa Ingreso Corte $N^{\circ}$ 514-2007).

${ }^{18}$ Véase los ejemplos citados en Garcia, "Ofensas", cit. nota n. 12, pp. 179 y 180.

${ }^{19}$ Véase Aguilera, Las causas, cit. nota n. 10, p. 212.

${ }^{20}$ Esa es la posición que, en su momento, asumió la doctrina comparada, tal como puede verse en Cabanellas, Guillermo, Tratado de Derecho Laboral, T. II, vol. 3, Heliasta, tercera edición, Buenos Aires, 1988, p. 216.
} 
ilícito que la agresión se encuentre consumada ya que en la práctica el diseño legal advierte un nivel muy intenso de gravedad en la simple amenaza ${ }^{21}$, en los supuestos de $\operatorname{acoso}^{22} \mathrm{o}$ incluso en la ocurrencia de lesiones leves.

En materia laboral, tampoco resulta necesario dejar huellas o rastros perceptibles de algún daño, toda vez que la causal se estructura como una figura de mera actividad. En razón de lo anterior, el simple ánimo o intención (verificada en actos positivos) de crear en el amenazado el temor de sufrir un daño específico, puede llegar a resultar suficiente para estimar la concurrencia de la causal aun cuando parte de la jurisprudencia le ha restado gravedad a determinados arrebatos de prepotencia ${ }^{23}$. No obstante, ha sido la misma jurisprudencia la que ha indicado que constituye causa justificada de terminación del contrato consistente en vías de hecho "la conducta conflictiva y frecuentemente ofensiva del trabajador respecto del personal de la empresa" ${ }^{\prime 24}$.

Consecuente con lo anterior, para poder aplicar la causal no se requiere un grado determinado de resultado lesivo, pues la ocurrencia de la infracción no tiene por qué estar vinculada a la magnitud del daño o a la contundencia de la acción ${ }^{25}$. Esto implica que, no necesariamente, las vías de hecho deben traer aparejado un contacto físico ya que la causa disciplinaria perfectamente

\footnotetext{
${ }^{21}$ Véase por todas sentencia de la Excma. Corte Suprema de 30 de octubre de 2003 (Causa Ingreso Corte $\left.\mathrm{N}^{\mathrm{0}} 788-2003\right)$.

${ }^{22}$ La particular situación de acoso laboral, derivado de las vías de hecho, ha sido en parte resuelta por la Ley № 20.603, de 08 de agosto de 2012, que modificó el Código del Trabajo, sancionando las prácticas de acoso en el trabajo. Para estos efectos, la nueva ley agrega una frase en el inciso segundo del artículo $2^{\circ} \mathrm{CT}$, en el sentido de que es "contrario a la dignidad de la persona el acoso laboral, entendiéndose por tal toda conducta que constituya agresión u hostigamiento reiterados, ejercida por el empleador o por uno o más trabajadores, en contra de otro u otros trabajadores, por cualquier medio, y que tenga como resultado para el o los afectados su menoscabo, maltrato o humillación, o bien que amenace o perjudique su situación laboral o sus oportunidades en el empleo". Desde esta perspectiva, la ejecución de agresiones u hostigamientos por parte del trabajador y que provoque menoscabo, maltrato o humillación, puede constituir no sólo causal de despido por la norma del artículo $160 \mathrm{~N}^{\circ} 1$, letra c) CT (si es que efectivamente se verifica a través de vías de hecho); sino que, además, puede dar origen a un despido por acoso laboral del trabajador a sus compañeros de labores.
}

${ }^{23}$ La jurisprudencia particular que ha limitado la aplicación de esta hipótesis extintiva, sostuvo que los "arrebatos de palabra o prepotencia, si bien pueden atentar contra normas de urbanidad, no alcanzan a constituir falta de honradez, vías de hecho, injurias ni conducta inmoral". Véase sentencia de la Iltma. Corte de Apelaciones de Santiago de 27 de octubre de 1983, GJ No 41, 1983, p. 77. De igual modo, la jurisprudencia también se ha encargado de delimitar las figuras propias de "vías de hecho" de aquellas que simplemente se traducen en injurias. Por ejemplo, véase la sentencia de la Excma. Corte Suprema de 11 de julio de 2010 (Causa Ingreso Corte № 2601-2010).

${ }^{24}$ Véase sentencia de la Iltma. Corte de Apelaciones de Santiago de 08 de enero de 1988, RDJ, T. LXXXV, sección tercera, 1988, p. 34.

${ }^{25}$ Véase IGARtua Miro, María Teresa, "Ofensas verbales o físicas", El despido: análisis y aplicación práctica, coordinación de Juan Gorelli Hernández, Tecnos, Madrid, 2004, p. 89. 
puede producirse por actos de coacción o provocaciones que no implican una riña propiamente tal ${ }^{26}$.

Por último, hay que tener presente que los hechos constitutivos de la causal muchas veces se presentan rodeados de otras figuras extintivas. Así ocurre, por ejemplo, con las injurias, que en innumerables casos complementa simultáneamente la agresión con epítetos ofensivos y degradantes del ofendido. Con todo, y como ya se ha insinuado, ambas figuras son radicalmente distintas pues en las vías de hecho lo que se sanciona es un actuar físico (no verbal) más allá de la existencia de determinados insultos ${ }^{27}$.

\section{El contexto en el cual se produce la infracción}

Las vías de hecho se estructuran en un evidente cuadro contractual. Lo que el legislador busca sancionar son infracciones a los deberes contractuales, evitando cualquier alternativa que pretenda extender el poder disciplinario del empleador a cuestiones de carácter extralaboral. Desde esa perspectiva, el contexto en el cual se produce la infracción resulta determinante para calificar el hecho cuestionado, y dicho contexto, debe ser configurado desde una óptica principalmente laboral. Así lo ratifica el Código al hacer referencia a los sujetos que intervienen en la acción prohibida, y así se deriva también de la exigencia legal de que la falta sea ejecutada en contra de trabajadores de "la misma empresa". Por tanto, el contexto no puede ser sino laboral y contractual.

Salvo excepciones, el contexto laboral y contractual se presume por la mera ocurrencia del hecho en el lugar de trabajo y durante la jornada laboral ${ }^{28}$. Lo anterior se ve reafirmado por la propia redacción que utiliza el artículo 160 № 1 letra c) CT, en el sentido que se trata de vías de hecho ejercidas en contra del empleador o de cualquier trabajador que se desempeñe "en la misma empresa".

El elemento locativo no debe ser confundido como una simple referencia a las instalaciones físicas del empleador; más bien, debe vincularse con aquél

\footnotetext{
${ }^{26}$ Una posición contraria puede consultarse en la sentencia de la Iltma. Corte de Apelaciones de La Serena de 29 de diciembre de 2003 (Causa Ingreso Corte No 2600-2003): "En efecto, la 'casi agresión física' se encuentra lejos de constituir vías de hecho ejercidas contra el empleador (...)". A una conclusión similar a la señalada en el cuerpo de este artículo, se ha llegado por parte de la doctrina comparada española (Agullera, Las causas, cit. nota n. 10, p. 211) y argentina (CABANELLAS, Tratado, cit. nota n. 19, T. II, vol. 3, p. 216).

${ }^{27}$ Véase García, "Ofensas", cit. nota n. 12, p. 179. Véase además el caso descrito en la sentencia de la Iltma. Corte de Apelaciones de Santiago de 19 de octubre de 2001, GJ № 258, 2001, p. 179. Véase también la sentencia de la Excma. Corte Suprema de 08 de julio de 2010 (Causa Ingreso Corte № 26012010), la cual concluyó que las "reiteradas faltas de respeto a sus superiores, mediante expresiones groseras, desmedidas y fuera de control" no forman parte de la causal consistente en vías de hecho.

${ }^{28}$ Véase sentencia de la Iltma. Corte de Apelaciones de La Serena de 07 de mayo de 1999 (Causa Ingreso Corte № 1538-1999).
} 
ámbito organizativo cuya titularidad le corresponde al empleador. De igual modo, la referencia a la jornada se entiende íntimamente asociada al espacio de tiempo que el trabajador destina a ejecutar las obligaciones que le impone el contrato. Por ello, los hechos ejecutados después de la jornada o, incluso, durante el feriado legal, no debieran en principio ser considerados en la calificación de la causal ${ }^{29}$. A pesar de lo anterior, a nivel de la doctrina comparada se acepta que queden incorporados dentro del ámbito espacial los períodos de tiempo destinado a pausas o descansos específicos dentro de la jornada ${ }^{30}$.

Con todo, la valoración jurisprudencial del contexto ha sido dispar: en algunos casos, se tiende a evaluar restrictivamente esta noción asociándola con el tiempo efectivo de trabajo ${ }^{31}$; y, en otros, la conexión con lo laboral se entremezcla con una mínima exigencia del factor causal. Es decir, más allá del lugar y del espacio de tiempo, lo relevante sería que las vías de hecho se produjeron por "causa o con ocasión del trabajo"32, evidenciando una conexión entre el hecho infraccional y el trabajo propiamente tal pues lo que se busca proteger es la convivencia interna y la disciplina propia de la organización ${ }^{33}$.

Lo expuesto no impide la sanción de hechos íntimamente relacionados con el trabajo, aun cuando su ejecución se haya verificado fuera de las instalaciones de la empresa o incluso más allá de los tiempos de trabajo. En esta línea, parte

\footnotetext{
${ }^{29}$ Véase sentencia de la Iltma. Corte de Apelaciones de Valdivia de 17 de octubre de 1991, RFM № 403, 1992, p. 352: Debe declararse injustificado el despido "que se funda en hechos cometidos (por el trabajador) cuando iniciaba su feriado legal y el día anterior era domingo, que de acuerdo a su contrato no estaba obligado a trabajar, y cuando ejecutaba funciones que no eran inherentes a las que debía cumplir".
}

${ }^{30}$ Véase la posición planteada en el Derecho español por SAGARDor BengoeCHEA, Juan Antonio, "Las riñas o pendencias", Dieciséis lecciones sobre causas de despido, Sección de Publicaciones e Intercambio Facultad de Derecho Universidad de Madrid, Madrid, 1969, p. 206.

${ }^{31}$ Véase sentencia de la Excma. Corte Suprema de 25 de enero de 2007 (Causa Ingreso Corte № 43672005): "Tercero: (...) los sentenciadores tuvieron por establecido que si bien el demandante participó en una riña con un compañero de trabajo, ésta se desarrolló en el sector en que los trabajadores se cambian de ropa y descansan, por lo que no trascendió a los clientes de la demandada ni afectó el desarrollo de la actividad de la empresa, todo lo que le resta al incidente la gravedad requerida por la norma legal ya referida y, en razón de lo cual, declararon injustificado el despido y ordenaron el pago de las indemnizaciones solicitadas".

${ }^{32}$ Véase sentencia de la Excma. Corte Suprema de 03 de septiembre de 1942, RDJ T. XL, sección primera, 1943, p. 164: "El tribunal sentenciador al establecer que los actos que sancionan la terminación del contrato deben ocurrir entre las partes contratantes, dentro del establecimiento y en horas de trabajo, impone exigencias que no son necesarias para dar por cumplida la causal". En el plano doctrinal, véase Cabanellas, Tratado, cit. nota n. 19, T. II, vol. 3, p. 215: “(...) debe exigirse una conexión de causa a efecto entre el altercado y la relación laboral".

${ }^{33}$ Véase SAGARDor, "Las riñas", cit. nota n. 30, p. 206: "(...) la reyerta aun obedeciendo a motivos personales, puede producir perjuicio a la empresa porque altere el orden en el centro de trabajo". En el plano jurisprudencial, véase sentencia de la Excma. Corte Suprema de 08 de julio de 2010 (Causa Ingreso Corte $N^{\circ}$ 2601-2010). 
de la doctrina ha justificado la medida extintiva cuando la agresión se produjo inmediatamente después de concluidas las tareas del día y por causas de orden laboral ${ }^{34}$, o fuera de la jornada laboral aunque dentro del establecimiento de la empresa ${ }^{35}$. En el fondo, este criterio flexible del tiempo y del lugar permite incorporar dentro de la causal todos aquellos hechos que se han producido a causa o con ocasión del trabajo ${ }^{36}$, independientemente de si ellos se han verificado al interior del lugar físico donde funciona la empresa o bien durante el cumplimiento de una determinada jornada ${ }^{37}$.

Desde esta perspectiva, y salvo aquellos actos que se ejecuten por "causa o con ocasión del trabajo", toda agresión fuera del ámbito y contexto laboral quedaría en principio excluida de la hipótesis lega ${ }^{38}$. Lo expuesto no es óbice para que se exija una conexión más intensa entre el ámbito donde se prestan

\footnotetext{
${ }^{34}$ Véase la posición mantenida en el Derecho argentino por Cabanellas, Tratado, cit. nota n. 19, T. II, vol. 3, p. 215: "La agresión a un capataz, (...) cuando la agresión obedece a cuestiones de trabajo, aun cuando se concrete fuera del establecimiento, constituye hecho que cabe calificar como falta justificada de despido (...)".

${ }^{35}$ Véase el supuesto de hecho existente en la sentencia de la Iltma. Corte de Apelaciones de La Serena de 07 de mayo de 1999 (Causa Ingreso Corte № 1538-1999), en que se consideró justificado el despido de un trabajador que agredió físicamente a un subordinado, antes de la hora de inicio de la jornada laboral respectiva y dentro del recinto laboral
}

${ }^{36}$ Véase Lizama Portal, Luis, Derecho del Trabajo. LexisNexis, Santiago, 2003, p. 173, y Rojas Miño, Irene, Manual de Derecho del Trabajo, LexisNexis, Santiago, 2004, p. 248.

${ }^{37}$ Parte de la jurisprudencia ha asumido este criterio cuando señala que "(...) la circunstancia verdaderamente trascendente a los efectos de esa calificación es si las vías de hecho se han producido a causa o con ocasión de la relación laboral o no, con completa independencia del lugar físico o geográfico en que ellas se producen. (...) si como ocurre justamente en este caso, la agresión se produce fuera del lugar y horario de trabajo, pero se vincula causalmente con hechos acaecidos nítidamente en el marco de la relación laboral (en la especie, según se explicó, la molestia de las demandantes por haber comunicado la supervisora el despido de un primo), esa agresión puede perfectamente justificar el despido del artículo $160 \mathrm{~N}^{\circ} 1$ letra C del Código del Trabajo, aunque se haya realizado en lugar y tiempo ajeno a la jornada laboral, puesto que la relación laboral exige un trato si no cordial, al menos cabalmente respetuoso por ambas partes" (véase sentencia de la Iltma. Corte de Apelaciones de Valdivia de 29 de octubre de 2008. Causa Ingreso Corte No 142-2008).

${ }^{38}$ Véase sentencia de la Iltma. Corte de Apelaciones de Santiago de 11 de noviembre de 1992, RFM 414, 1993, p. 306: "Si bien el (trabajador) se trabó en pendencia con un compañero de trabajo, diciendo que éste lo insultó, ocurre que tal hecho sucedió en un recinto privado, fuera del local de ventas, por tanto no tuvo lugar en presencia del público. Sin calificar las razones que haya tenido el demandante para trabarse en pendencia con otro vendedor, es lo cierto que ello no afecta a la buena marcha del establecimiento comercial, y no hubo ofensas dirigidas a los jefes o empleadores"; y sentencia de la Iltma. Corte de Apelaciones de Talca de 24 de mayo de 2011 (Causa Ingreso Corte № 67-2011): "La causal prevista en el artículo $160 \mathrm{~N}^{\circ} 1$ letra c) del Código del Trabajo se refiere a conductas relacionadas con la prestación de los servicios del trabajador dentro de la empresa, dejando fuera aquéllas acciones censurables que el trabajador pudiere realizar fuera del ámbito laboral". Lo anterior no implica, por cierto, que los hechos extralaborales sean absolutamente, y en cualquier circunstancia, "irrelevantes para el correcto cumplimiento del contrato en todos los casos y en todos los trabajos" (véase FERNÁNDEZ, El poder, cit. nota n. 10, p. 190). 
los servicios y las vías de hecho. Es decir, más allá de que las riñas o peleas se produzcan al interior de la empresa, o durante el tiempo de trabajo, lo relevante sería que éstas se llevasen a cabo en el contexto de la relación laboral ${ }^{39}$, produciéndose una relación causal entre el hecho reprochado y el ámbito de ejecución del contrato.

Por último, habrá que tener presente que alguna jurisprudencia ha asociado la pertinencia de la causal con la existencia de un perjuicio específico para el empleador. Así, por ejemplo, la sentencia de la Excma. Corte Suprema de 06 de marzo de 1993 consideró injustificado el despido de un trabajador que se trabó en pendencia con un compañero de labores, ya que esto sucedió en un recinto privado "fuera del local de ventas de la empresa, y por tanto, sin presencia de público, (cuestión) que no afecta la buena marcha del establecimiento comercial $^{\prime 40}$. Desde luego, una cosa es la buena marcha de la empresa y otra distinta es el perjuicio o daño efectivo que se le provoca al empleador, asunto que ha obligado a que parte de la doctrina ponga el acento en la necesidad de que la conducta indebida perturbe el orden dentro de la actividad laboral del establecimiento, independiente de si ha existido o no perjuicio ${ }^{41}$. Por lo demás, acreditada la gravedad de la falta, la existencia o no de perjuicios reales, ciertos, directos o indirectos, termina siendo irrelevante pues en este tipo de causales lo que importa es la situación de riesgo que se provoca a partir de un hecho ${ }^{42}$.

\section{El sujeto pasivo de la acción}

El Código del Trabajo circunscribe la causa disciplinaria a aquellas agresiones dirigidas en contra del empleador o bien en contra de cualquier trabajador

\footnotetext{
${ }^{39}$ Así lo resolvió la sentencia de la Iltma. Corte de Apelaciones de Santiago de 18 de julio de 2005, GJ № 319, 2007, pp. 326 y ss.: "El despido por las causales de vías de hecho (...) por haber participado en una discusión verbal y corporal con caracteres de riña con un compañero de trabajo, en el lugar de trabajo y durante el horario de atención a público, pero que tuvo lugar en el sector en que los trabajadores se cambian de ropa y descansan, implica que la riña no trascendió a los clientes de la demandada ni afectó al desarrollo de la actividad de la empresa en modo alguno, por lo que permite declarar al despido como injustificado por carecer de la gravedad necesaria". Véase también la sentencia de la Iltma. Corte de Apelaciones de Valdivia de 29 de octubre de 2008 (Causa Ingreso Corte № 142-2008): “(...) si en una discusión un trabajador propina un golpe o empujón a su empleador porque estima que éste se ha insinuado de modo poco decoroso a su cónyuge, la agresión no se vincula causalmente con el contenido ético jurídico de la relación laboral, y por lo tanto resulta inepta para fundamentar un despido (...)".

${ }^{40}$ Véase sentencia de la Excma. Corte Suprema de 06 de marzo de 1993, Repertorio de Legislación y Jurisprudencia Chilenas. Código del Trabajo y Leyes complementarias, T. I., Dirección de Héctor Humeres Noguer, Editorial Jurídica de Chile, Santiago, 2002, p. 187.

${ }^{41}$ Véase Cabanellas, Tratado, cit. nota n. 19, T. II, vol. 3, p. 215.

${ }^{42}$ Véase por todos Irureta Uriarte, Pedro, "Vigencia del principio de la buena fe en el Derecho del Trabajo chileno", Revista lus et Praxis Año 17 № 2, 2011, p. 180.
} 
que se desempeñe en la misma empresa. Como ya se ha dicho, a partir de la reforma legal introducida por la Ley № 19.759 (de 2001), el Código restringe la aplicación de la causal en comparación con el texto utilizado desde el año 1924 en adelante. En efecto, durante todo el siglo XX el legislador sancionaba cualquier vía de hecho independientemente de quién era el sujeto pasivo de la acción. De esta manera, y con redacción de contornos abiertos, se sancionaban los actos de violencia en contra de los clientes de la empresa, de familiares del empleador o lisa y llanamente en contra de cualquier persona que se relacionara con la actividad productiva.

Modificando el criterio anterior, durante la tramitación de la Ley № 19.759 (de 2001) los senadores señores Lavandero, Ruiz De Giorgio y Ruiz-Esquide, presentaron una indicación en orden a que las causales del artículo $160 \mathrm{~N}^{\circ} 1$ $\mathrm{CT}$ estuviesen fundadas en conductas indebidas (graves y comprobadas) consistentes, entre otras, en "vías de hecho ejercidas por el trabajador en contra del empleador o de cualquier trabajador que se desempeñe en la misma empresa". Según los autores de la indicación, el único objetivo del cambio propuesto era "hacer hincapié en que todas estas conductas deben relacionarse con la actividad de la empresa, puesto que la ley actual no lo deja claramente de manifiesto, corriéndose el riesgo que algún empleador pudiera intentar acciones contra un trabajador por actos realizados fuera del ámbito de la empresa" ${ }^{\prime 3}$. Esta modificación fue ampliamente aprobada, tanto en la Cámara como en el Senado, dejando la redacción actual en los términos que ya se ha indicado; es decir, el sujeto pasivo de las vías de hecho es el "empleador" y "cualquier trabajador que se desempeñe en la misma empresa" ${ }^{44}$.

La determinación de la figura del empleador, en tanto sujeto pasivo, no debiera generar mayores inconvenientes. Tanto el empleador persona física como su representante pueden ser sujetos pasivos de las vías de hecho. También lo son los representantes de la persona jurídica que actúa como empleador. Por tanto, toda persona natural que ocupe la posición jurídica de empleador (ya sea porque ostenta de manera directa la titularidad, o bien porque actúa como representante del titular) puede ser catalogado como sujeto pasivo de la infracción. Por el contrario, en caso alguno la persona jurídica empleadora puede ser considerada como sujeto pasivo de las vías de hecho.

Las personas allegadas o estrechamente vinculadas al empleador por vínculos de parentesco o de amistad, no debieran formar parte de un eventual sujeto

\footnotetext{
${ }^{43}$ Véase. la intervención del senador Ruíz De Giorgio en el Informe de la Comisión de Trabajo del Senado, Bibloteca del Congreso Nacional, Historia de la Ley No 19.759 Modifica el Código del Trabajo en lo relativo a las nuevas modalidades de contratación, al derecho de sindicación, a los derechos fundamentales del trabajador y a otras materias que indica, p. 497.

${ }^{44}$ Véase Lizama, Derecho, cit. nota n. 36, pp. 172 y 173.
} 
pasivo, ya que el artículo 160 № 1 CT es taxativo al indicar que las vías de hecho deben ir dirigidas en contra del empleador y no en contra de otro tipo de personas vinculadas a él. Con todo, una dificultad adicional surge en el caso de los socios integrantes de una persona jurídica empleadora. Desde una perspectiva meramente formal, las agresiones en contra de estas personas no debieran quedar cubiertas en la hipótesis del artículo 160 № 1, letra c) CT: ellos no son el empleador y tampoco lo representan a efectos laborales. Lo anterior no implica que este tipo de conductas queden completamente impunes, ya que si las vías de hecho han afectado al socio integrante de la persona jurídica (o incluso a personas estrechamente vinculadas), y ello tiene una clara connotación laboral, entonces perfectamente podría argumentarse que en la especie se ha producido un incumplimiento grave de las obligaciones que impone el contrato (art. $\left.160 \mathrm{~N}^{\circ} 7 \mathrm{CT}\right)^{45}$.

De igual forma, el Código acepta que sea sujeto pasivo de la infracción "cualquier trabajador que se desempeñe en la misma empresa". En principio, la voz trabajador abarca a todo dependiente laboral del mismo empleador; es decir, compañeros de labores que mantienen el mismo tipo de vínculo jurídico independientemente de si se encuentran en una posición jerárquica superior o inferior $^{46}$. Este fue el criterio que mantuvo doctrina y jurisprudencia durante toda la vigencia del Código de 1931, y también durante la aplicación del Código de $1994^{47}$, cuestión que fue refrendada por la modificación de la Ley № 19.759 (de 2001). Y ello es entendible, si se parte de la base que el fundamento de esta causal radica precisamente en la convivencia interna y en la disciplina mínima necesaria para llevar a cabo las labores y cumplir el vínculo contractual.

No obstante, también deben entenderse involucrados dentro de los sujetos pasivos de la infracción a aquellos trabajadores que prestan servicios en una empresa subcontratista o bien en una Empresa de Servicios Transitorios relacionada con el empleador. Ellos también tienen la calidad de trabajadores "en la misma empresa", e incluso mantienen un vínculo indirecto de orden laboral con el empleador titular de la organización. Más aún, la propia redacción del artículo $160 \mathrm{~N}^{\circ} 1$ letra c) CT deja abierta esta alternativa al indicar que se

\footnotetext{
${ }^{45}$ No ocurre lo mismo en el caso de las injurias, en que parte de la jurisprudencia la ha estimado aplicable para el caso de que el trabajador profiera ofensas en contra del socio principal de la sociedad empleadora. Sobre el particular, véase sentencia de la Excma. Corte Suprema de 03 de abril de 1997, RDJ T. XCIV, sección tercera, 1997, p. 35.

${ }^{46}$ Véase, una conclusión similar a la planteada, por parte de la doctrina comparada, en SAAVEDRA ACEVEDO, Jerónimo, "Los malos tratos y faltas de respeto como causa justa de despido", Dieciséis lecciones sobre causas de despido, Sección de Publicaciones e Intercambio Facultad de Derecho Universidad de Madrid, Madrid, 1969, p. 101.

${ }^{47}$ Véase, por todas, sentencia de la Iltma. Corte de Apelaciones de Santiago de 02 de noviembre de 1990, RFM No 396, 1991, p. 720: “(...) dicha causal (se refiere a las vías de hecho) no se limita a las agresiones contra el empleador".
} 
trata de "cualquier trabajador que se desempeñe en la misma empresa". Esta interpretación de la norma legal permite concluir, además, que pueden tener la calidad de sujetos pasivos de la infracción los trabajadores de la empresa principal o de la empresa usuaria.

El caso de otras personas vinculadas al empleador en razón de otro tipo de vínculos es más discutible. Una parte de la doctrina ha justificado el despido en razón de agresiones contra personas ajenas a la empresa, "siempre que tales actos se materialicen en ocasión o como consecuencia del trabajo"48. Allí cabrían, por ejemplo, las agresiones a los mandatarios, clientes o proveedores del empleador, a personas que mantienen contratos a honorarios o incluso a aquellos que se vinculan en razón de actividades meramente comerciales. En el fondo, la incorporación de estas personas dentro de la hipótesis de los sujetos pasivos debe fundarse en la ocurrencia de la infracción dentro del contexto laboral. Ello exige, necesariamente, un examen caso a caso en sede judicial, a objeto de determinar si efectivamente existe algún nexo o factor causal de índole laboral que explique la sanción de las agresiones cometidas. Con todo, en estos casos lo más congruente sería fundar la decisión extintiva en la causal del artículo $160 \mathrm{~N}^{\circ} 7 \mathrm{CT}$ (siempre y cuando se reúna la gravedad suficiente), pues la modificación legal introducida por la Ley № 19.759 (de 2001) circunscribió de manera significativa el alcance de las vías de hecho en relación con el sujeto pasivo $^{49}$. No hay que olvidar que dentro de los deberes contractuales, ciertamente habrá que incluir aquellos vinculados a la disciplina interna necesaria para el desempeño adecuado de las labores. Desde esta perspectiva, no tendría mayor justificación la realización durante la jornada laboral de agresiones físicas en contra de personas que se vinculan con la empresa ${ }^{50}$.

\footnotetext{
${ }^{48}$ Véase la posición mantenida en el Derecho argentino por CABAnellas, Tratado, cit. nota n. 19, T. II vol. 3, p. 214.

${ }^{49}$ Este criterio lo invocó parte de la jurisprudencia hasta antes de la reforma de 2001. Ese fue el caso, por ejemplo, de la sentencia de la Excma. Corte Suprema de 20 de noviembre de 1990 (RFM № 396 [1991], p. 717), que acogiendo un recurso de queja concluyó que la agresión física injustificada del trabajador a un compañero de labores configura la causales de vías de hecho y de incumplimiento grave de las obligaciones. En igual sentido, sentencia de la Iltma. Corte de Apelaciones de Valparaíso de 20 de octubre de 1983, GJ № 40, 1983, p. 113. Con todo, una posición contraria puede consultarse en la sentencia de la Excma. Corte Suprema de 04 de enero de 1984 (Rol № 4.994): "El despido del actor se basó en (...) falta de probidad e incumplimiento grave de las obligaciones que le imponía el contrato. Sin embargo, el trabarse en pendencia con otro obrero de la barraca de la demandada (...) no constituye falta de probidad. En cuanto al incumplimiento grave de las obligaciones que le imponía el contrato, dicha causal tampoco pudo ser acogida por no conocerse las obligaciones y funciones específicas del actor (...)". En Thayer Arteaga, William, y Rodríguez Alvarado, Antonio, Código del Trabajo y Legislación Social, Editorial Jurídica de Chile/Editorial Jurídica Ediar ConoSur Ltda., Santiago, 1988, p. 322. Véase también RojAs, Manual, cit. nota n. 36, p. 248.

${ }^{50}$ La misma posición se mantiene, a nivel doctrinal, por Macchiavello Cuneo, Guido, Derecho del Trabajo T. I, Fondo de Cultura Económica, Santiago, 1986, p. 519.
} 
Cabe hacer presente, en todo caso, que la redacción actual del Código es más restrictiva que la existente en otros ordenamientos de nuestro entorno. En México, por ejemplo, el artículo 47 de la Ley Federal sanciona una figura similar al incurrir el trabajador en "actos de violencia, amagos, injurias o malos tratamientos" en contra del empleador, del personal directivo o administrativo o en contra de alguno de sus compañeros, "salvo que medie provocación o que obre en defensa propia". Igual derrotero sigue el artículo 482, letra j), de la Consolidación de las Leyes del Trabajo de Brasil, el cual sanciona las ofensas físicas practicadas en el servicio, "contra cualquier persona", salvo los casos de legítima defensa propia o de otro.

\section{El sujeto activo de la acción}

El sujeto activo de la causal, por cierto, es el trabajador, independientemente de la posición que ostente dentro de la organización. Así lo dispone el artículo 160 № 1 CT, al configurar la causal como "vías de hecho ejercidas por el trabajador". Desde luego, a éste se le hace responsable del acto prohibido cuando lo ejecuta por sí mismo y en razón de diversas modalidades de agresión; o bien cuando ha concebido el ilícito o instigado a su realización ${ }^{51}$. Ese sería el caso del trabajador inductor, forzador o instigador, que forma en otro individuo (dependiente o no del empleador) la resolución infractora. Por el contrario, el trabajador que encubre el hecho no debiera verse afectado por esta específica causal (sin perjuicio de otras que eventualmente pudiesen aplicársele) ya que por definición el encubridor actúa cuando la conducta está terminada, sea en fase de tentativa, frustración o consumación. ${ }^{52}$

También se entiende incorporado al trabajador (como sujeto activo de la infracción), cuando éste tolera la ejecución de las vías de hecho por parte un tercero, dentro del ámbito de la empresa, omitiendo todo tipo de auxilio. Desde luego, se parte de la base que el trabajador ha tenido la posibilidad racional y cierta de oponerse a la vías de hecho, ya que en caso contrario no podría exigírsele un comportamiento que desborda su propia capacidad. Lo que ocurre en este caso, es que la actitud pasiva y de tácita aquiescencia refleja una participación laboralmente reprochable, cuestión que ha llevado a configurar ese tipo de situaciones dentro de un supuesto típico de malos tratos de obra ${ }^{53}$. Igualmente, parte de la doctrina tiende a ampliar los supuestos de ofensa físi-

\footnotetext{
${ }^{51}$ Véase, en el plano de la doctrina comparada, Gomez Abelleira, Francisco Javier, "Las causas disciplinarias del despido", El despido. Dirección de Antonio V. Sempere Navarro. Aranzadi-Thomson Reuters, segunda edición, Pamplona, 2009, p. 240.

${ }^{52}$ Véase los criterios que a este respecto se utilizan en el ordenamiento penal, en GarRIDO, Derecho, cit., nota n. 3, T. II, p. 297.

${ }^{53}$ Véase Aguilera, Las causas, cit. nota n. 10, pp. 212 y 213.
} 
ca cuando ellos son cometidos por familiares o acompañantes que el propio trabajador introdujo en la empresa; pero, en rigor, lo que se sanciona en estos casos es que el trabajador se abstuvo de intervenir pudiendo haber evitado que una persona vinculada a él ejecutara las vías de hecho ${ }^{54}$.

\section{LAS ATENUANTES, AGRAVANTES Y EXIMENTES DE LA CAUSAL}

Como se indicó con anterioridad, la ejecución de las vías de hecho siempre es considerada un acto grave. Los contratantes del vínculo laboral tienen la obligación de respetar las normas de convivencia y la disciplina interna que exige la ejecución del contrato, razón por la cual parte de la doctrina ha concluido que un acto de indisciplina consistente en agredir a un superior jerárquico o a un compañero de labores siempre debe ser visto como un acto justificativo del despido, incluso cuando "el responsable sea un trabajador con antigüedad que no había sido sancionado hasta entonces" ${ }^{\prime \prime 5}$. Desde esta perspectiva, existe menos tolerancia para este tipo de figuras que la que podría existir para otro grupo de causales cuya evaluación se ve mediatizada por elementos más atenuantes.

Con todo, la práctica jurisprudencial, así como el análisis doctrinal, han establecido un conjunto de criterios complementarios que se consideran en la calificación de la causal. Dichos criterios se traducen en la aparición de verdaderas atenuantes, agravantes o eximentes de responsabilidad que permiten circunscribir los alcances de la figura.

\section{La agravación de la conducta}

Ya se ha dicho que, en lo que respecta a las vías de hecho, la tendencia es a considerarlas esencialmente graves (más allá de si se trata de un acto aislado o reiterativo). No obstante, existen circunstancias que permiten reafirmar la relevancia de la infracción y que conceptualmente podríamos encuadrar dentro supuestas agravantes.

En materia de agravantes, existen circunstancias que reafirman no sólo la gravedad de la conducta sino que, además, la necesidad de extinción del contrato. Entre dichas agravantes destacan supuestos tales como el hecho de desempeñar

\footnotetext{
${ }^{54}$ Véase García, "Ofensas", cit. nota n. 12, p. 199.

${ }^{55}$ Esta es la posición que ha asumido, en el Derecho argentino, Vázquez VIALARD, Antonio, Tratado de Derecho del Trabajo, T. 5. Astrea, Buenos Aires, 1993, p. 393. Con todo, en nuestro país, alguna jurisprudencia le ha asignado a la antigüedad una cierta cualidad tendiente a atenuar la gravedad de las vías de hecho. Así ocurrió, por ejemplo, en la sentencia de la Iltma. Corte de Apelaciones de Santiago de 11 de julio de 1997, GJ № 205, 1997, p. 165, “(...) el incidente de que se trata no encierra la gravedad que para tal efecto debe concurrir, máxime que no aparece probado de manera alguna que el demandante en los cuatro años de labores, hubiera con anterioridad tenido conflictos con sus compañeros o en su desempeño laboral".
} 
cargos de confianza de mayor significación al interior de la empresa; la realización de actos preparatorios que dejan en evidencia la alevosía o premeditación con la cual se ha actuado; el uso de medios completamente desproporcionados en la agresión; la reiteración de la conducta prohibida; o la ejecución de vías de hecho con resultado de lesiones, entre otras alternativas ${ }^{56}$.

A pesar de lo anterior, la valoración de eventuales agravantes en la ejecución de las vías de hecho debe ser evaluada en el contexto de las exigencias de la buena fe. En efecto, el catálogo de causales del artículo 160 CT se inspira en los deberes propios de aquella, caracterizados por la corrección y lealtad de los contratantes. En esta perspectiva, la buena fe no admite grados ${ }^{57}$, sin que sea posible exigir mayores deberes de corrección en determinados supuestos y en otros no. En materia de buena fe no puede existir graduación cuantitativa de la infracción, de allí que, si existe gravedad en la conducta que amerita el despido, la presencia de eventuales agravantes no debiera ser especialmente significativa para calificar el acto cuestionado. De todas formas, la aparición de hipotéticas circunstancias agravantes cumple un evidente rol didáctico pues reafirma la gravedad de la conducta. Por ello, superado el umbral de la gravedad, la existencia de circunstancias que cuantitativamente aumenten la calificación de dicha gravedad no debiera ser óbice para determinar la procedencia del despido. No es que el despido vaya a ser más gravoso por la concurrencia de estas especiales circunstancias. Por el contrario, un determinado acto rodeado de estas circunstancias que eventualmente pueden denominarse como agravantes, permite calificar en su conjunto la gravedad de la actuación reprochada.

\section{La reacción frente a un acto provocado por un tercero}

De manera prácticamente uniforme, la jurisprudencia laboral ha venido exigiendo desde antiguo que en el origen de las vías de hecho haya participado el trabajador. Su participación, como resulta lógico, puede producirse en distintos grados (sea como autor directo, cómplice, instigador o inductor), pero lo que resulta indispensable es que al trabajador se le pueda imputar la ejecución de la agresión sin que haya existido una provocación previa ${ }^{58}$.

Si este requisito no se cumple, y el trabajador sólo se ha limitado a una mera reacción frente a la provocación externa, la conclusión entonces es que

\footnotetext{
${ }^{56}$ Véase alguno de estos supuestos en autores de Derecho comparado tales como AguilerA, Las causas, cit. nota n. 10, pp. 45 y 46.

${ }^{57}$ Véase, por todas, sentencia de la Excma. Corte Suprema de 14 de diciembre de 1981, RFM № 277, 1981, p. 590.

${ }^{58} \mathrm{Si}$ las riñas han tenido su origen en agresiones mutuas y recíprocas, aceptadas por ambos intervinientes, la gravedad del hecho disminuye aun cuando surge un problema ulterior: "el relativo a la inadecuación de despedir sólo a uno de los sujetos" (véase, IGARTUA, "Ofensas", cit. nota n. 25, p. 89).
} 
al trabajador no le es imputable la causal ${ }^{59}$. Dicha provocación se traduce en actos destinados a irritar o a estimular al trabajador de palabra o de obra. Y, desde esta perspectiva, el hecho de repeler una agresión en legítima defensa, fundado en la existencia de una provocación previa e inmediata, eximen de responsabilidad al trabajador $^{60}$. De esta forma, la agresión que da origen a la legítima defensa debe vincularse con los comportamientos activos del agredi$\mathrm{do}^{61}$, de modo tal que la mera omisión del sujeto pasivo no da derecho a repeler mediante vías de hecho.

Desde luego, para que proceda la exención de responsabilidad se requiere que la provocación sea, por una parte, real, ilegítima e inminente; y, por la otra, que el trabajador agredido reaccione mediante una respuesta racional al daño causado. Que la agresión inicial sea real, implica que la ofensa física sea verdadera y suficiente para crear en el trabajador una alteración de tal nivel que se ve obligado a reaccionar frente a la agresión inicial ${ }^{62}$. Ello obliga a desechar los ataques imaginarios o meramente temidos por el trabajador, pero que no han llegado a ocurrir. Esto es especialmente aplicable a las amenazas de agresiones futuras y verosímiles, en las cuales el trabajador sólo se encontraría habilitado para tomar precauciones lícitas que permitan prevenir eventuales vías de hecho en su contra. También se requiere que la hipotética agresión inicial no esté autorizada por el Derecho (que sea ilegítima), ya que en ese caso no puede haber legítima defensa por parte del trabajador. Ello ocurriría, por ejemplo, si el trabajador repele un acto de detención de la fuerza pública en razón de una orden judicial, ya que en modo alguno podría alegar una eximente de esta naturaleza. Por último, resulta preciso que la agresión que justifique la reacción del trabajador sea inminente o inmediata, de forma tal que éste no tenga que esperar a que el ataque se materialice.

Como contrapartida, la defensa del trabajador debe ser racional y en función de la necesidad de defenderse. Dentro de la racionalidad habrá que incluir la justificación del medio empleado para repeler la agresión, cuestión que obliga a considerar tanto las circunstancias personales del agresor como las características del hecho mismo. Si la aparente defensa esconde otro tipo de motivaciones, o

\footnotetext{
${ }^{59}$ Véase sentencia de la Iltma. Corte de Apelaciones de Concepción de 12 de septiembre de 1991, G) № 136, 1991, p. 133: "Para que concurra la causal vías de hecho se hace necesario que el trabajador despedido haya agredido a un tercero; no ocurre esta situación, si la actora sólo se limitó a repeler la agresión de su compañera de labores". En igual sentido, véase sentencia del Noveno Juzgado de Letras del Trabajo de Santiago de 25 de mayo de 1978, y que fuese ratificada por la Excma. Corte Suprema, GJ № 21, 1979, p. 43: “(...) no aparece acreditada la causal de caducidad del contrato 'vías de hecho', desde el momento en que la actora se había visto envuelta en una rencilla sin que existiera provocación de su parte".

${ }^{60}$ Véase García, "Ofensas", cit. nota n. 12, p. 203.

${ }^{61}$ Véase GarRIDO, Derecho, cit. nota n. 3, T. II, p. 130.

${ }^{62}$ Véase IGartua, "Ofensas", cit. nota n. 25, p. 89.
} 
bien la agresión está precedida de otra intencionalidad, entonces difícilmente podría colocarse en movimiento la estructura laboral de esta figura ${ }^{63}$.

Finalmente, y por aplicación de las reglas generales, habrá que concluir que el trabajador puede actuar en legítima defensa de su persona o de sus derechos ${ }^{64}$. Es decir, la reacción defensiva del trabajador se justifica no sólo cuando hay agresiones a su integridad corporal sino que, también, a cualquier otro derecho ligado a su persona, tales como la propiedad, la libertad o incluso el honor.

\section{El retraso desleal en la aplicación de la causal}

A partir del principio de la buena fe, la jurisprudencia ha venido aplicando desde antiguo la exigencia tendiente a establecer una relación temporal próxima entre el hecho infraccional y la sanción del despido ${ }^{65}$. Esto es lo que doctrinariamente se conoce como el retraso desleal o bien (en materia de extinción contractual) como el perdón de la causal.

Lo que subyace en esta corriente jurisprudencial es la idea de que si el empleador ha tenido, frente a una infracción disciplinaria del trabajador, una conducta omisiva durante un tiempo relevante, entonces razonablemente el afectado puede esperar que no se ejercite el derecho respectivo en su contra. Como lo indica parte de la doctrina comparada, "un retraso en la decisión de despedir crea la confianza de que no se ha tenido en cuenta la falta; es, pues, contrario a la buena fe valerse de una causa antigua para despedir al trabajador" ${ }^{\prime \prime 6}$. De esta manera, si el empleador no ejerce su derecho en la oportunidad correspondiente, entonces deberá entenderse que perdió la posibilidad de invocar posteriormente las acciones respectivas ${ }^{67}$.

Ciertamente, la figura del retraso desleal ha sido utilizada en distintas materias de orden disciplinario. También ha sido profusamente invocada en otras causales del artículo 160 CT como una exigencia de seguridad del trabajador,

\footnotetext{
${ }^{63}$ Ese es el caso descrito en Politoff, Matus y Ramírez, respecto de un grupo de trabajadores de una empresa minera que en el año 1928 se mutilaron unos a otros los dedos para cobrar una indemnización. Lo que se verificaba allí es un caso de autolesión destinado a defraudar (ya sea al empleador o a los organismos de seguridad social), pero en caso alguno existía agresión al estilo de las vías de hecho. Sobre el particular, véase Poltioff L., Sergio, Matus A., Jean Pierre, y Ramírez G., María Cecilia, Lecciones de Derecho Penal, Parte Especial. Editorial Jurídica de Chile, segunda edición, Santiago, 2005, p. 114, nota 10.

${ }^{64}$ Véase por todos Garrido, Derecho, cit., nota n. 3, T. II, p. 129.

${ }^{65}$ Véase Gamonal Contreras, Sergio, y Guidi MogGia, Caterina, Manual de Contrato de Trabajo, Abedelo Perrot/LegalPublishing Chile, Santiago, 2011, p. 278.

${ }^{66}$ Véase GIL y GIL, José Luis, "La buena fe en el contrato de trabajo", RTSS, 1996, p. 34.

${ }^{67}$ Véase en esta línea, y por todas, sentencia de la Excma. Corte Suprema de 29 de diciembre de 2005, G) $N^{\circ} 308,2006$, p. 158, y sentencia de la Iltma. Corte de Apelaciones de Santiago de 27 de octubre de 1986, GJ No 7, 1986, p. 80.
} 
quien no puede estar indefinidamente inmerso bajo la posibilidad de ser sancionado en cualquier momento por infracciones cometidas en un pasado sin límite de tiempo ${ }^{68}$. La omisión del empleador crea la confianza en el trabajador en orden a que su eventual infracción no reúne los criterios de gravedad que ameritan el despido.

Aspectos de este criterio exculpatorio de responsabilidad, en el caso específico de las vías de hecho, ha sido esgrimido por la jurisprudencia para rechazar el despido de un trabajador que agredió a un empleador meses antes del acto extintivo: "atendido el tiempo transcurrido, no podría considerarse que es la referida actitud la motivación del despido; aun cuando se estimara injusta la agresión, no existiría entre ese hecho y la separación, el nexo de causalidad que se precisa" ${ }^{\prime 69}$. En el fondo, se parte de la hipótesis que "entre el hecho que sirve de base para un despido y la materialización del mismo debe existir algún grado de simultaneidad"70.

\section{La indeterminación sobre el autor inicial de la agresión}

Otro punto relevante en la aplicación de la causal se refiere a la determinación del autor. Una mínima exigencia de comprobación y seguridad jurídica obliga a que exista certeza sobre la identidad del autor que ejecutó la agresión reprochada. Si éste no se encuentra identificado con claridad, difícilmente podrá invocarse la causal con respecto a un trabajador determinado, ya que la sanción sólo puede recaer en aquél que dio origen a las vías de hecho ${ }^{71}$.

Desde esta perspectiva, la indeterminación del autor exime de responsabilidad a un trabajador específico ${ }^{72}$, pues lo que no puede ocurrir es que la máxima

\footnotetext{
${ }^{68}$ Véase IrURETA, "Vigencia", cit., nota n. 43, p. 148, nota 50.

${ }^{69}$ Véase sentencia de la Iltma. Corte de Apelaciones de Santiago de 27 de octubre de 1983, GJ № 41, 1983, p. 77.

${ }^{70}$ Véase sentencia de la Iltma. Corte de Apelaciones de Rancagua de 21 de junio de 2004 (Causa Ingreso Corte No 4344-2004): "QUINTO: Que, conforme a lo expuesto anteriormente y atendida la abundante jurisprudencia de nuestros Tribunales y de nuestra Excma. Corte Suprema en orden a que, entre el hecho que sirve de base para un despido y la materialización del mismo debe existir algún grado de simultaneidad y más de 45 días de diferencia entre uno y otro hecho, no reúne la característica exigida y más bien se debe entender que de haber existido una conducta laboral impropia por parte del actor, esta fue menor y medió, por parte del demandado, perdón por la falta cometida y, consecuencialmente, ella no constituye vías de hechos ejercidas por el demandante en contra del empleador o algún trabajador que se desempeñe en la misma empresa". En el plano doctrinal, véase Gil y GIL, José Luis, Autotutela privada y poder disciplinario en la empresa. Centro de Publicaciones del Ministerio de Justicia, Madrid, 1993, p. 132.

${ }^{71}$ Véase sentencia de la Excma. Corte Suprema de 30 de octubre de 2003. Causa Ingreso Corte № 788-2003.

${ }^{72}$ Véase, en esta línea, sentencia de la lltma. Corte de Apelaciones de Santiago de 28 de junio de 1999, GJ № 228, 1999, p. 165: “(...) no habiéndose establecido en modo alguno en autos cuál de los dos
} 
sanción disciplinaria del despido se aplique en base a meras sospechas. Esta exigencia, predicable de todas las causas disciplinarias, resulta especialmente relevante en el caso de las vías de hecho pues la figura reprochada es más concreta que otras hipótesis extintivas.

Lo que ocurre es que la práctica laboral deja en evidencia situaciones en las cuales la producción de riñas, peleas o agresiones no permite aclarar con exactitud al autor inicial del acto. Con todo, si varios trabajadores participan en una riña (sin que sea posible identificar al provocador inicial), se tiende a aceptar doctrinariamente que la sanción del despido sea predicable para todos los que participaron en el ilícito laboral pues en definitiva todos ellos infringen la disciplina interna necesaria ${ }^{73}$.

\section{Las vías de hecho provocadas en supuestos de alteración síquica}

La realización de vías de hecho bajo un estado de alteración sicológica, que priva la capacidad de entendimiento, atenúa la responsabilidad o incluso, en algunos casos, la elimina ${ }^{74}$. La alteración sicológica provoca un defecto de conducta y se manifiesta mediante una turbación pasajera de las potencias, lo cual muchas veces tiene su origen, por regla general, en el consumo de alcohol o de otros estupefacientes (sean lícitos o ilícitos). En ese estado, la calificación sobre la gravedad de la conducta se ve atenuada ya que no existe una total voluntariedad en la ejecución de las vías de hecho.

Cierta corriente doctrinal tiende a distinguir aquellos casos en que el trabajador se ha expuesto imprudentemente a la influencia del alcohol o de estupefacientes. No obstante, si la causal invocada es concretamente las vías de hecho (no el consumo de alcohol o de sustancias prohibidas, lo cual por sí mismas pueden dar origen a otro tipo de causales), entonces lo más lógico es concluir que al momento del consumo el trabajador no está en condiciones de prever la comisión de las vías de hecho ni tampoco sus consecuencias.

Las consideraciones anteriores encuentran una excepción en aquellos casos en que el trabajador sabe o debiera saber por experiencias previas que el consumo de alcohol o de estupefacientes lo arrastra a la comisión de vías de

partícipes en el incidente habría dado inicio indebido a una agresión determinada en contra del otro, no ha podido acreditarse en perjuicio del actor las vías de hecho constitutivas de la causal de despido invocada por el empleador".

${ }^{73}$ Véase, en el plano de la doctrina comparada, Aguilera, Las causas, cit. nota n. 10, p. 214. Véase también, a nivel comparado, CREMADES, Bernardo María, La sanción disciplinaria en la empresa, Instituto de Estudios Políticos, Madrid, 1969, p. 136.

${ }^{74}$ Véase Aguilera, Las causas, cit. nota n. 10, p. 213. 
hecho en contra de otras personas en el ámbito de la empresa ${ }^{75}$. Esa conciencia de la posterior comisión de la infracción, elimina cualquier eximente en la calificación del acto. Igual derrotero se producirá cuando el trabajador consume sustancias etílicas o estupefacientes con la precisa finalidad de ejecutar el acto indebido.

Con todo, la jurisprudencia nacional tiende a distinguir en esta materia tres tipos de estadios: la alteración motivada por el consumo no habitual, el habitual y el patológico. De estas tres hipótesis, la embriaguez o toxicomanía habitual encuadraría en una actuación grave que amerita el despido ya que ciertamente el trabajador debiera prever las consecuencias que se derivan de su actuación. Él tiene la capacidad de resistir el consumo y, por tanto, las consecuencias que pueden derivar del mismo. Al no hacerlo, resulta imposible alegar que el hecho lo ha superado. En el caso de consumos no habituales de sustancias etílicas o de estupefacientes, y por tratarse de un hecho aislado y esporádico, la conducta prohibida tiende a no revestir los caracteres de gravedad que ameritan el despido (salvo, por cierto, en aquellos casos en que el cargo o función exijan una conducta intachable a este respecto). Por último, el consumo patológico es asimilado a un supuesto de enfermedad ya que en rigor el trabajador no tiene la capacidad de resistir dicho consumo que, a su vez, trae como consecuencia la ejecución de las vías de hecho ${ }^{76}$.

\section{CONCLUSIONES}

1. La configuración del núcleo definitorio de las vías de hecho en el ámbito del despido disciplinario, se ha estructurado en términos amplios, cuestión que permite incorporar dentro del mismo a todo tipo de agresiones físicas, riñas, peleas o pendencias que provoque el trabajador. La ejecución de las mismas no suponen necesariamente la pura agresión corporal o la comisión de lesiones, ya que, en definitiva, lo que se busca proteger es la disciplina interna necesaria para realizar las labores.

2. La configuración amplia de las vías de hecho, ha supuesto aceptar como parte del núcleo definitorio de la causal a figuras tales como las amenazas, las provocaciones o, incluso, los meros intentos de agresión, independiente de si se

\footnotetext{
${ }^{75}$ Para un análisis de la reflexión existente, sobre esta materia, en el Derecho penal, véase por todos Roxın, Klaus, Derecho Penal, T. I, traducción de Diego-Manuel Luzón Peña, Miguel Díaz y García Conlledo, y Javier de Vicente Remesal, Civitas, primera edición, Madrid, 1997, pp. 841 y ss.

${ }^{76}$ Sobre el particular, véase la posición de las distintas corrientes jurisprudenciales en IRURETA URIARTE, Pedro, "La falta de probidad como causa de extinción del contrato de trabajo", Libro homenaje al profesor William Thayer Arteaga, Editado por Sociedad Chilena de Derecho del Trabajo y Seguridad Social, Santiago 1998, pp. 124 y ss.
} 
produce o no un resultado determinado. De esta manera, la causal se estructura como una infracción de mera actividad sin que sea necesario dejar huellas o rastros perceptibles de algún daño.

3. Las vías de hecho deben producirse en un contexto laboral. Dicho contexto no se explica necesaria o exclusivamente por la circunstancia de que la infracción se haya ejecutado en el lugar de trabajo o durante la jornada laboral. Más bien, lo que se exige es que las vías de hecho se hayan producido a causa o con ocasión del trabajo, cuestión que permite ampliar los contornos del ámbito en el cual se lleva a cabo el ilícito. Este criterio flexible del tiempo y del lugar permite incorporar dentro de la causal todos aquellos hechos que se han producido a causa o con ocasión del trabajo, independientemente de si ellos se han verificado al interior del lugar físico donde funciona la empresa o bien durante el cumplimiento de una determinada jornada.

4. El sujeto activo de la causal será siempre el trabajador. Lo que ocurre es que doctrinaria y jurisprudencialmente se ha admitido que dicho sujeto puede intervenir en diversas alternativas tales como autor, instigador, inductor o forzador. También se entiende incorporado al trabajador (como sujeto activo de la infracción), cuando éste tolera la ejecución de las vías de hecho por parte de un tercero o compañero de labores, dentro del ámbito de la empresa, omitiendo todo tipo de auxilio, aun cuando ha tenido la posibilidad racional y cierta de oponerse a la vías de hecho. Lo que ocurre en este caso es que la actitud pasiva y de tácita aquiescencia refleja una participación laboralmente reprochable, cuestión que ha llevado a configurar ese tipo de situaciones dentro de un supuesto típico de malos tratos de obra.

5. El sujeto pasivo, por su parte, está centrado en el empleador y en otros trabajadores que se desempeñen en la misma empresa. El empleador sólo podrá ser la persona natural que ocupe dicha posición jurídica en calidad de titular o representante. En el caso de los demás trabajadores, se incluyen dentro de esta categoría a aquellos que mantienen vínculo laboral con el empleador, y los trabajadores del contratista o de una Empresa de Servicios Transitorios que laboran en la misma empresa. En el caso de otras personas que presten servicios para el empleador en calidad de mandatarios, clientes, proveedores, o personal a honorario, lo cierto es que las vías de hecho en contra de ellos puede ser perfectamente sancionada bajo la hipótesis de un incumplimiento grave de las obligaciones que impone el contrato de trabajo (art. $160 \mathrm{~N}^{\circ} 7 \mathrm{CT}$ ), siempre y cuando exista un factor causal que deje en evidencia el contexto laboral.

6. La calificación de las vías de hecho ha estado rodeada de circunstancias agravantes, atenuantes o eximentes. En el caso de las agravantes de conducta, ellas se han estructurado como elementos más bien didácticos que facilitan la calificación de gravedad. No obstante, si una determinada agresión reúne los 
caracteres de gravedad que exige el Código, entonces las eventuales agravantes más que aumentar la sanción lo que hacen es ilustrar los elementos necesarios para justificar el despido.

Jurisprudencialmente, las atenuantes han estado centradas en la figura de la legítima defensa. Si las vías de hecho son el resultado de una agresión previa de otro trabajador, o del mismo empleador, entonces la conducta del sujeto pasivo no debiera ser constitutiva de la causal de despido. Desde luego, la defensa del trabajador debe ser racional y en función de la necesidad de defenderse. Dentro de la racionalidad habrá que incluir la justificación del medio empleado para repeler la agresión, cuestión que obliga a considerar las circunstancias personales del agresor como las características del hecho mismo.

Dentro de las eximentes, la tendencia es a considerar que no existe justificación para el despido cuando el empleador ha retrasado indebidamente la decisión de despedir, cuando existe indeterminación del autor de las vías de hecho, y cuando la infracción se ejecuta bajo supuestos de alteración sicológica.

\section{BibliografíA CITADA}

Aguilera IzQuierdo, Raquel, Las causas del despido disciplinario y su valoración por la jurisprudencia, Aranzadi, Pamplona, 1997.

Baylos Grau, Antonio, "La valoración del comportamiento habitual del trabajador en el despido por malos tratos y faltas graves de respeto", RPS $\mathrm{N}^{\circ} 119$, 1978.

Cabanellas, Guillermo, Tratado de Derecho Laboral, T. II vol. 3, Heliasta, tercera edición, Buenos Aires, 1988.

CREMADES, Bernardo María, La sanción disciplinaria en la empresa, Instituto de Estudios Políticos, Madrid, 1969.

Fernández López, María Fernanda, El poder disciplinario en la empresa, Civitas, primera edición, Madrid, 1991.

Gamonal Contreras, Sergio, y Guidi Moggia, Caterina, Manual de Contrato de Trabajo, Abedelo Perrot/LegalPublishing Chile, Santiago, 2011.

GarCia Ninet, José Ignacio, "Ofensas verbales o físicas al empresario o a otras personas del entorno empresarial", Estudios sobre el despido disciplinario, Acarl, Madrid, 1992.

Garrido Montt, Mario, Derecho Penal T. III, Editorial Jurídica de Chile, cuarta edición, Santiago, 2010.

Gıl y GıL, José Luis, Autotutela privada y poder disciplinario en la empresa, Centro de Publicaciones del Ministerio de Justicia, Madrid, 1993.

_ _ "La buena fe en el contrato de trabajo", RTSS, 1996. 
Gomez Abelleira, Francisco Javier, "Las causas disciplinarias del despido", El despido, dirección de Antonio V. Sempere Navarro, Aranzadi-Thomson Reuters, segunda edición, Pamplona, 2009.

Humeres Noguer, Héctor, dirección, Repertorio de Legislación y Jurisprudencia Chilenas. Código del Trabajo y Leyes complementarias, T. I, Editorial Jurídica de Chile, Santiago, 2002.

Igartua Miro, María Teresa, "Ofensas verbales o físicas", El despido: análisis y aplicación práctica, coordinación de Juan Gorelli Hernández, Tecnos, Madrid, 2004.

IruReta Uriarte, Pedro, "Vigencia del principio de la buena fe en el Derecho del Trabajo chileno", Revista lus et Praxis, Año 17 N² 2, 2011.

, "La falta de probidad como causa de extinción del contrato de trabajo", Libro homenaje al profesor William Thayer Arteaga, Editado por Sociedad Chilena de Derecho del Trabajo y Seguridad Social, Santiago, 1998.

Lizama Portal, Luis, Derecho del Trabajo, LexisNexis, Santiago, 2003.

Luque Parra, Manuel, Los límites jurídicos de los poderes empresariales en la relación laboral, Bosch, Barcelona, 1999.

Macchiavello Cuneo, Guido, Derecho del Trabajo T. I, Fondo de Cultura Económica, Santiago, 1986.

Montoya Melgar, Alfredo, Derecho del Trabajo, Tecnos, vigésimo novena edición, Madrid, 2008.

Ortiz Lallana, M. Carmen, "Causas y formas del despido disciplinario (en torno a los artículos 54 y 55)", El Estatuto de los Trabajadores veinte años después, Civitas, primera edición, Madrid, 2000.

Politoff L., Sergio, Matus A., Jean Pierre, y Ramirez G., María Cecilia, Lecciones de Derecho Penal, Parte Especial, Editorial Jurídica de Chile, segunda edición, Santiago, 2005.

Rojas Miño, Irene, Manual de Derecho del Trabajo, LexisNexis, Santiago, 2004.

Roxın, Klaus, Derecho Penal, T. I, traducción de Diego-Manuel Luzón Peña, Miguel Díaz y García Conlledo, y Javier de Vicente Remesal, Civitas, primera edición, Madrid, 1997.

SaAvedra Acevedo, Jerónimo, "Los malos tratos y faltas de respeto como causa justa de despido", Dieciséis lecciones sobre causas de despido, Sección de Publicaciones e Intercambio Facultad de Derecho Universidad de Madrid, Madrid, 1969.

Sagardor Bengoechea, Juan Antonio, "Las riñas o pendencias", Dieciséis lecciones sobre causas de despido, Sección de Publicaciones e Intercambio Facultad de Derecho Universidad de Madrid, Madrid, 1969. 
Thayer Arteaga, William, y Rodriguez Alvarado, Antonio, Código del Trabajo y Legislación Social, Editorial Jurídica de Chile/Editorial Jurídica Ediar ConoSur Ltda., Santiago, 1988.

VÁzquez Vialard, Antonio, Tratado de Derecho del Trabajo, T. 5, Astrea, Buenos Aires, 1993. 